\title{
Pengaruh Model Pembelajaran Kooperatif Tipe Snowball Throwing Terhadap Hasil Belajar Sosiologi Siswa Kelas XI IIS Di SMA N 1 Batusangkar
}

\author{
Rahma Fitri ${ }^{1}$, Ike Sylvia ${ }^{2}$ \\ Universitas Negeri Padang ${ }^{3}$ \\ Email: rahmafitri22011998@gmail.com, ikesylvia@fis.unp.ac.id
}

\begin{abstract}
Abstrak
Penelitian ini dilatar belakangi rendahnya hasil belajar Sosiologi siswa kelas XI.IIS di SMA N 1 Batusangkar. Rendahnya hasil belajar siswa disebabkan karena dua faktor, yaitu eksternal dan internal. Salah satu faktor yang dapat ditingkatkan untuk meperbaiki mutu pembelajaran adalah dengan memvariasikan model pembelajaran salah satunya melalui model Snowball Throwing. Penelitian ini bertujuan untuk mengetahui pengaruh model pembelajaran kooperatif tipe Snowball Throwing terhadap hasil belajar Sosiologi siswa pada materi konflik sosial. Penelitian merupakan penelitian kuantitatif tipe eksperimen. Model rancangan penelitian yang digunakan adalah pretest dan posttest - Random Controll Group Postess Design. Populasi penelitian ini adalah siswa kelas XI.IIS SMA N 1 Batusangkar tahun pelajaran 2019/2020. Dari tiga kelas, dipilih dua kelas yaitu XI.IIS 1 sebagai kelas eksperimen dan XI.IIS 3 sebagai kelas kontrol. Teknik analisis data penelitian menggunakan uji normalitas data yang terdiri dari uji homogenitas dan uji hipotesis. Analisis data diperoleh skor rata - rata di kelas eksperimen $=83,23$ dan untuk kelas kontrol diperoleh rata - rata $=76,91$ dan $t_{\text {hitung }}=13386$ dan $\mathrm{t}_{\text {tabel }}=0,10744$ pada $\alpha=0,05 . \mathrm{H}_{1}$ diterima dan $\mathrm{H}_{0}$ ditolak. Artinya terdapat pengaruh model pembelajaran pengaruh model pembelajaran kooperatif tipe Snowball Throwing terhadap hasil belajar sosiologi siswa.
\end{abstract}

Kata kunci: Hasil Belajar, Model Pembelajaran, Snowball Throwing, Pembelajaran Sosiologi

\section{Abstract}

This research is backed by the low learning results of the sociology of students from XI class in high school N 1 Batusangkar. The low student learning outcomes are due to two factors, external and internal, one of the factors that can be improved to improve the quality of learning is by varying the learning model of one of them through the Snowball Throwing model. The research aims to determine the influence of a Snowball Throwing-type cooperative learning model of Student sociology learning outcomes on social conflict materials. This research is a quantitative research of experimental types. The Model of the research draft used is pretests and posttest-Random Controll Group Postess Design. The population of this research is XI grade students. IIS SMA N 1 Batusangkar year lesson 2019/2020. Of the three classes, the two classes are selected XI. IIS 1 as an experimental and XI class. IIS 3 as the control class. Research data analysis techniques use data normality test consisting of homogeneity test and hypothesis test. Data analysis obtained the average score in the experiment class $=83.23$ and for the control class obtained on average - average $=76.91$ and thitung $=$ 1.3866 and this $=0.10744$ at $\alpha=0.05$. H1 accepted and HO rejected. This means that there is the influence of the Snowball Throwing type Cooperative learning model of student learning outcomes

Keywords: Learning Model, Snowball Throwing, Learning Outcomes, Sociology Learning

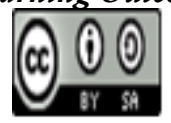

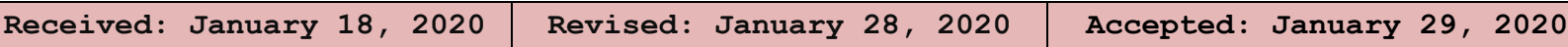




\section{Pendahuluan}

Kemajuan dalam sains dan teknologi memainkan peran penting dalam semua aspek kehidupan manusia. Pesatnya perkembangan ilmu pengetahuan dan teknologi kini memiliki dampak besar pada semua bidang kehidupan manusia, salah satunya adalah pendidikan. (Melinda \& Sylvia, 2012). Pendidikan adalah upaya untuk mempersiapkan siswa untuk memainkan peran mereka sebagai manusia di masa depan (Triastuti, Mujasam, Sri, Wahyu, \& Irfan, 2017). Sekolah adalah lembaga pendidikan formal pertama yang sangat penting dalam menentukan hasil belajar siswa (Triastuti et al., 2017). Dalam konteks pembangunan manusia Indonesia seutuhnya, pengembangan pendidikan adalah alat dan alat yang penting dan menentukan untuk pengembangan sumber daya manusia. Karena itu, sektor pendidikan harus dan harus menerima perhatian, perawatan, dan prioritas dari pemerintah, masyarakat pada umumnya, dan manajer pendidikan pada khususnya (Susanto \& B, 2014).

Pembelajaran dapat diartikan sebagai proses kerja sama antara guru dan siswa dalam memanfaatkan semua potensi dan sumber daya yang ada, baik dari siswa itu sendiri maupun dari dunia luar. (Sanjaya, 2009). Kegiatan belajar mengajar mengembangkan kemungkinan yang dibawa sejak lahir. Komponen yang ada dalam kegiatan pembelajaran meliputi guru dan siswa. Seorang guru harus memiliki pengetahuan, keterampilan dan sikap profesional ketika mengajar siswa. Oleh karena itu belajar adalah proses perkembangan manusia untuk meningkat dan berubah (Iga, Fathia, Agus, \& Susanna, 2017).

Pembelajaran kreatif akan menciptakan situasi yang menyenangkan bagi siswa selama proses pembelajaran dengan melibatkan siswa secara aktif dapat meningkatkan pemahaman siswa tentang materi dan kemampuan berpikir (Rasyid \& Side, 2011). Pendidikan diselenggarakan untuk memastikan bahwa siswa memiliki keterampilan untuk hidup di masyarakat atau yang biasa disebut keterampilan hidup (Raguwan, Gonggo, \& Sabang, 2014). Kurangnya ketajaman keterampilan siswa dalam komunikasi dan kerja sama merupakan masalah penting yang menghambat proses pembelajaran. Pembelajaran sosiologi adalah pembelajaran yang membutuhkan aspek kognitif, dalam hal ini benar-benar membutuhkan keterampilan 4C (berpikir kritis, komunikasi, kolaboratif dan kreatif) (Dendy, Marta \& Nurlizawati, 2019). Hasil belajar sering digunakan sebagai tolok ukur untuk mengetahui sejauh mana seseorang menguasai materi pembelajaran. Hasil belajar dapat dijelaskan dengan memahami dua kata yang mereka bentuk, yaitu "hasil" dan "belajar". Wawasan tentang hasil menunjukkan akuisisi sebagai hasil dari melakukan suatu kegiatan atau proses yang mengarah pada perubahan input fungsional, sementara pembelajaran dilakukan untuk mencari perubahan perilaku pada individu yang belajar (Purwanto, 2009).

Kurikulum nasional yang digunakan dalam pembelajaran saat ini dikenal dengan nama kurikulum 2013, telah memberikan arahan jelas bahwa peserta didik wajib memiliki pengalaman belajar dengan memberikan penekanan perlunya penyelidikan ilmiah (inquiry) agar peserta didik mampu melakukan sinkronisasi antara materi yang dipelajari dan realita yang ada disekitarnya (authentic), dengan harapan peserta didik mampu mengkonstruksi konsep serta melatih kemampuan metakognitifnya. (Sylvia et al., 2019). Tujuan kurikulum 2013 sesuai dengan Permendikbud No. 36 tahun 2018 tentang perubahan Permendikbud 59 tahun 2014 tentang kurikulum 2013 adalah: (1) Mempersiapkan orang Indonesia untuk kemampuan hidup sebagai individu dan warga negara yang setia, produktif, kreatif, inovatif, dan afektif. (2) Mampu berkontribusi pada kehidupan masyarakat, bangsa, negara dan peradaban dunia.

Untuk mencapai tujuan kurikulum 2013, tantangan berikutnya adalah guru abad 21 perlu mempersiapkan peserta didik yang unggul dan memiliki kecakapan tersebut. Tugas guru adalah mendesain, melaksanakan pembelajaran sesuai dengan rancangannya, serta mampu mengevaluasinya. Selain itu guru juga perlu memikirkan cara mentransformasikan kecakapan tersebut ke dalam diri para peserta didiknya melalui perencanaan, pelaksanaan, dan evaluasi pembelajarannya secara terarah, efektif dan efisien. Dengan dibekali kecakapan ini sebagai

Jurnal Sikola: Jurnal Kajian Pendidikan dan Pembelajaran Vol. 1, No. 3, Th. 2020 
tambahan kecakapan akademik peserta didik akan terbantu memecahkan permasalahan individual dan sosial yang dihadapi dalam kehidupan di lingkungannya. (Sylvia et al., 2019) Untuk itu guru harus pintar menggunakan model yang tepat sehingga siswa termotivasi dan tertarik dengan proses pembelajaran dan hasil belajar juga meningkat. Dalam proses pembelajaran, guru sebagai fasilitator harus dapat memilih pendekatan, metode dan model pembelajaran yang tepat dan menentukannya dengan topik yang akan dipelajari, sehingga pembelajaran dapat dilakukan secara efektif dan tujuan pembelajaran dapat berhasil dicapai (Sukir, 2009).

Studi pendahuluan yang penulis lakukan di SMA N 1 Batusangkar, terlihat bahwa guru sosiologi telah menerapkan model pembelajaran yang bervariasi, dengan metode diskusi dan tanya jawab. Namun, dalam pelaksanaannya, selama pembelajaran, hanya 4 sampai 6 orang siswa saja yang ikut berpartisipasi aktif dalam menjawab pertanyaan guru. Jarang ditemukan siswa yang mau bertanya pada guru, kalaupun ada siswa yang bertanya hanya 1 atau 2 orang saja dalam setiap kelas, akibatnya pembelajaran kembali terpusat pada guru dan peran siswa dalam proses pembelajaran berkurang. Siswa yang aktif merupakan siswa yang sama pada setiap pertemuan. Salah satu penyebanya adalah praktek pembelajaran lebih sering diskusi dan mepresentasikan tugas mereka sehingga menjadi monoton, akibatnya aktifitas siswa selama proses pembelajaran berkurang dan hasil belajar yang diperoleh relatif rendah.

Faktor-faktor yang mempengaruhi pembelajaran adalah faktor internal dan faktor eksternal. Faktor internal, termasuk: kecerdasan, perhatian dan minat. Selanjutnya, faktor eksternal, termasuk: aspek keluarga, aspek sekolah. Aspek sekolah ini terdiri dari metode pengajaran, hubungan guru-murid dan disiplin. Model, metode, media, teknik dan taktik mengajar yang kurang sesuai mempengaruhi proses dan hasil pembelajaran siswa. Untuk memastikan bahwa siswa dapat belajar dengan baik, perangkat pembelajaran dibuat semenarik mungkin serta dilaksanakan sesuai dengan perencanaan. Selain itu, guru yang tidak berinteraksi edukatif dengan siswa dapat dipastikan bahwa proses belajar mengajar berjalan kurang lancar. (Hapnita, Abdullah, Gusmareta, \& Rizal, 2018).

Dari permasalahan di atas, perlu menggunakan model pembelajaran yang tepat, yaitu model yang mampu membuat seluruh siswa terlibat dalam suasana pembelajaran yang diserasikan dengan pengembangan media pembelajaran yang sesuai sebagai dengan materi pembelajaran. Guru dituntut menggunakan model pembelajaran yang dapat mengajak siswa untuk secara aktif ikut terlibat dalam proses pembelajaran, sehingga dapat meningkatkan prestasi belajar siswa. Model Snowball Throwing merupakan permainan seperti melempar bola salju dan merupakan strategi pembelajaran itu dapat mendorong siswa untuk mengajukan pertanyaan dan jawaban untuk merangsang keaktifan belajar siswa (Yuli \& Tri, Astuti, 2015)

Model Snowball Throwing memiliki beberapa fitur, termasuk: (1). Siswa bekerja dalam kelompok kooperatif untuk menguasai materi akademik, (2). Siswa diminta mempraktikkan pemahaman siswa tentang materi, (3). Penilaian yang diberikan dalam pembelajaran kooperatif didasarkan pada hasil kerja kelompok. Namun, guru harus menyadari bahwa pencapaian aktual yang diharapkan adalah kinerja setiap siswa (Zaini, 2008) Model pembelajaran Snowball Throwing terdiri dari beberapa tahapan yaitu:

1. Guru menyampaikan materi yang akan disajikan

2. Guru membentuk kelompok-kelompok dan memanggil masing-masing ketua kelompok untuk memberikan penjelasan tentang materi

3. Masing-masing ketua kelompok kembali kekelompoknya kemudian menjelaskan materi yang disampaikan oleh guru kepadanya.

4. Masing-masing peserta didik diberi satu lembar kertas, untuk menuliskan satu pertanyaan apa saja yang menyangkut materi yang sudah dijelaskan oleh ketua kelompok.

5. Kemudian kertas yang berisi pertanyaan tersebut dibuat seperti bola dan dilempar dari satu peserta didik ke peserta didik yang lainnya selama lebih kurang 15 menit 
6. Setelah peserta didik dapat satu bola/satu pertanyaan diberi kesempatan kepada peserta didik untuk menjawab pertanyaan yang tertulis dalam kertas berbentuk bola tersebut secara bergantian (Sohimin, 2014)

Berdasarkan uraian diatas, maka peneliti tertarik untuk melakukan penelitian dengan judul "Pengaruh model pembelajaran kooperatif tipe Snowball Throwing terhadap hasil belajar Sosiologi siswa kelas XI IIS pada materi konflik sosial di SMA N 1 Batusangkar".

\section{Metode Penelitian}

Sesuai dengan permasalah yang diteliti, maka jenis penelitian ini termasuk penelitian kuantitatif dengan tipe eksperimen Random Controll Group Postess Design. Penelitian ini dilaksanakan pada siswa kelas XI.IIS SMA N 1 Batusangkar. Dalam penelitian ini, diambil dua kelas sebagai sampel yaitu kelas eksperimen yang dikenakan perlakuan yaitu penerapan model Snowball Throwing dalam pembelajaran kooperatif, sedangkan pada kelas eksperimen kontrol, pembelajaran yang dilakukan adalah pembelajaran kooperatif tanpa menggunakan model Snowball Throwing. Dalam penelitian ini tehnik pengumpulan data yang dapat digunakan adalah tes, dengan pemberian soal kepada siswa untuk melihat kemampuan dasar siswa (pre test) dan melihat pengaruh perlakuan model pembelajaran kooperatif tipe Snowball Throwing pada materi konflik sosial serta ketuuntasan belajar siswa melalui post test. Data dianalisis menggunakan rumus t-test.

\section{Hasil dan Pembahasan}

Dalam penelitian ini peneliti memperoleh data setelah melakukan pretes dan posttest pada dua kelas yaitu kelas XI IIS 1 dan XI IIS 3. Kelas XI IIS 1 adalah kelas eksperimen dan kelas XI IIS 3 adalah kelas kontrol. Jumlah siswa kelas eksperimen 36 orang dan kelas kontrol 36 orang. Pretest dilakukan untuk memastikan kesamaan kemampuan awal kelas kontrol dan kelas eksperimen sebagai sebuah syarat dapat dianalisis lebih lanjut pengaruh perlakuan model Snowball Throwing pada materi konflik sosial terhadap hasil belajar siswa. Berikut adalah penjelasan data pretest siswa.

\section{Pretest}

Skor rata-rata siwswa stelah diberikan soal pretest mengenai materi konflik sosial pada kelas kontrol sebesar 65,38 dan kelas eksperimen 62,56. Walaupun secara kasat mata ternyata rata-rata hasil belajar siswa mengalami perbedaan, namun peneliti tetap melakukan analisis data preteset tersebut melalui analisis rumus Uji T. Perbedaan pretest kelas eksperimen dan kelas kontrol dapat dilihat pada tabel:

Tabel 1. Perbandingan Nilai Pretest Pada Kelas Eksperimen Dan Kelas Kontrol

\begin{tabular}{ccccccc}
\hline Kelas & $\mathbf{N}$ & Nilai rata - rata & $\mathbf{S}$ & $\boldsymbol{S}^{\mathbf{2}}$ & $\boldsymbol{t}_{\text {hit }}$ & \multirow{2}{*}{$\boldsymbol{t}_{\text {tab }}$} \\
\cline { 1 - 5 } Kontrol & 36 & 65,38 & 1,92 & 3,6864 & & \multirow{2}{*}{6,14} \\
\cline { 1 - 5 } Eksperimen & 36 & 62,56 & 1,98 & 3,9204 & & 2,030 \\
\hline
\end{tabular}

Dari tabel di atas dapat dilihat perbedaan rata-rata kelas eksperimen dengan kelas kontrol yang tidak jauh berbeda. Setelah dilakukan uji t pretest tidak terdapat perbedaan antara kelas eksperimen dan kelas kontrol dimana thitung $=6,14$ sedangkan dengan taraf nyata 0.05 diperoleh $=2,030$ berarti ( $t$ hitung $>t$ tabel). Berdasarkan analisis diatas, peneliti berasumsi data tersebut

Jurnal Sikola: Jurnal Kajian Pendidikan dan Pembelajaran Vol. 1, No. 3, Th. 2020 
homogen, sehingga data yang diolah untuk uji hipotesis adalah data yang diperoleh dari hasil soal posttest di kelas XI IIS 1 dan XI IIS 3.

Setelah malakukan pretest pada pertemuan pertama pada kelas eksperimen dan kelas kontrol maka peneliti melakukan uji coba pelaksanaan model Snowball Throwing sebanyak 4 kali pertemuan. emudian pada pertemuan terakhir peneliti memberikan posttest kepada siswa. Banyak pertemuan disesuaikan dengan materi dan jadwal pertemuan pembelajaran sosiolosi di sekolah tempat penelitian. Materi pelajaran yang diberikan pada kelas eksperimen adalah konflik sosial. Posttest ini bertujuan untuk melihat pencapaian hasil belajar siswa serta pengaruh perlakuan model Snowball Throwing terhadap hasil belajar siswa.

\section{Post Test}

Dari hasil skor posttest diperoleh data rata - rata hasil belajar siswa, standar deviasi dan varians kelas eksperimen serta kelas kontrol. Hasil analisis posttest menunjukkan bahwa kelas eksperimen memiliki nilai rata - rata lebih tinggi dari kelas kontrol, data tersebut dapat dilihat pada tabel berikut:

\section{Tabel 2. Perbandingan Hasil Posttest Kelas Eksperimen dan Kelas Kontrol}

\begin{tabular}{ccccccc}
\hline Kelas & $\mathbf{N}$ & $\begin{array}{c}\text { Nilai rata } \\
\text { rata }\end{array}$ & $\mathbf{S}$ & $\boldsymbol{S}^{\mathbf{2}}$ & $\boldsymbol{t}_{\text {hit }}$ & $\boldsymbol{t}_{\text {tab }}$ \\
\hline Kontrol & 36 & 76,92 & 1,4003 & 70,6505 & & \\
\cline { 1 - 5 } Eksperimen & 36 & 83,23 & 1,0860 & 42,4924 & & 0,10744 \\
\hline
\end{tabular}

Diketahui bahwa rata-rata kelas eksperimen lebih baik dibanding rata-rata hasil belajar kelas kontrol, $\mathrm{t}$ hit $>\mathrm{t}$ tab, artinya terdapat perbedaan hasil belajar sosiologi antara proses pembelajaran dengan menggunakan Model Snowball Throwing pada siswa kelas XI.IIS di SMAN 1 Batusangkar, Kabupaten Tanah Datar.

Pembelajaran model Snowball Trowing merupakan model pembelajaran yang melibatkan siswa bekerja sama dalam kelompok kecil yang terdiri dari 1-5 orang dan masing-masing kelompok diberikan materi yang akan dibahas dalam kelompoknya, setiap kelompok saling membantu untuk mempelajari materi dengan berdiskusi.(Melinda \& Sylvia, 2012). Selanjutnya masing-masing kelompok diberi selembar kertas kerja untuk menulis pertanyaan yang menyangkut materi yang sedang didiskusikan dan jenis pertanyaan yang berhubungan dengan gambaran materi, sebab-akibat peristiwa dan pemecahan masalah dari sebuah konflik sosial, kemudian kertas tersebut dibuat seperti bola dan dilemparkan kepada kelompok lainnya, setelah masing-masing kelompok mendapat pertanyaan maka diberikan kesempatan untuk menjawab pertanyaan tersebut dan setiap kelompok bertanggung jawab terhadap nilai pribadi dan kelompoknya. Dengan model pembelajaran Snowball Trhowing siswa mampu membangun pemahaman melalui interaksi dengan kelompoknya dengan saling bekerja sama, saling membantu, yang akan meningkatkan kemampuan siswa dalam memahami, menganalisis materi, karena siswa berusaha untuk memahami materi dan berpikir bersama dalam mencari jawaban yang tepat dan dibantu pula oleh penjelasan dari guru. Pelaskanaan model Snowball Trhowing pada penelitian memiliki beberapa kelemahan yaitu tidak meratanya siswa yang bertanya dan menjawab pertanyaan serta siswa yang menanggapi sehingga seringkali siswa yang menanggapi pertanyaan adalah siswa yang itu-itu saja. Hal ini sesuai dengan apa yang dikatakan oleh Lorbach dan Tobin (Suparno, 1997) bahwa pengetahuan tidak dapat dipindahkan begitu saja dari otak seseorang dalam penelitian ini guru atau ketua kelompok, ke kepala orang lain (siswa). Siswa sendirilah yang harus mengartikan apa yang telah diajrkan dengan menyesuaikan terhadap pengalaman mereka. Artinya pemahaman siswa terhadap materi akan menjadi bertambah jika 
pendekatan yang digunakan dalam pembelajaran mampu mengajak siswa untuk berpikir dan mengkonstruksi materi tersebut dari fakta yang dipahaminya, kemudian siswa akan mampu belajar menganalsiis serta memecahkan masalah, mencari solusi secara bersama sama sehingga didapatkan suatu penyelesaian yang akurat. Jika ini dapat tercapai maka siswa diharapkan dapat melahirkan ide-ide baru yang kreatif. Untuk mengatasi keterbatasn ini, guru perlu mendengarkan dengan sungguh-sungguh interpretasi siswa mengenai materi yang dipelajarinya berdasarkan pertanyaan, jawaban dan tanggapan yang muncul, memperhatikan perbedaan siswa di dalam kelas dan memberikan penghargaan agar daapt memicu motivasi siswa, selain itu yang terpenting adalah jika siswa tidak mengerti terhadap materi yang dipelajarinya, dan tidak mampu maksimal mencapai tujuan kompetensi pembelajaran, makaitu adalah sesuatu yang berharga yang menjadi titik poin untuk memulai suatu perbaikan dalam pembelajaran berikutnya.

\section{Kesimpulan}

Pembelajaran Sosiologi pada materi konflik sosial menggunakan model Snowball Trhowing berpengaruh terhadap hasil belajar siswa. Hal ini dibuktikan dengan adanya peningkatan rata-rata skor pretest dengan skor posttest kelas kontrol dan eksperimen. Rata-rata skor pretest kelas kontrol 65,38 dan posttest kelas kontrol adalah 76,92. Sedangkan rata-rata skor prettest kelas eksperimen 62,56 dan posttest kelas eksperimen adalah 83,23. Uji hipotesis membuktikan terdapat pengaruh penerapan model pembelajaran yaitu model Snowball Throwing terhadap hasil belajar siswa, dengan t hit 1,3386 > t tabel 0,10744. Artinya walaupun pada aawalpembelajaran kelas kontrol memiliki skor rata-rata pretest lebih tinggi dari pada kelas eksperimen namun pada saat posttest dilakukan rata-rata kelas ekpserimen dapat berada jauh diatas rata-rata hasil belajar kelas kontrol. Selain itu standar deviasi kelas eksperimen jauh lebih kecil dibandingkan kelas kontrol, sehingga asumsi data skor hasil belajar siswa pada kelas eksperimen lebih homogen dibandingkan data skor rata-rata hasil belajar siswa pada kelas kontrol.

\section{Daftar Pustaka}

Dendy, Marta, P., \& Nurlizawati, N. (2019). Lesson Study dalam Meningkatkan Keterampilan 4C ( Critical Thingking, Collaborative, Communicative, dan Creative ) pada Pembelajaran Sosiologi yang Terintegrasi ABS_SBK Di SMAN 1 Pasaman. Jurnal Sikola: Jurnal Kajian Pendidikan Dan Pembelajaran, 1(2). https://doi.org/10.1017/CBO9781107415324.004

Hapnita, W., Abdullah, R., Gusmareta, Y., \& Rizal, F. (2018). Faktor Internal dan Eksternal yang Dominan Mempengaruhi Hasil Belajar Menggambar dengan Perangkat Lunak Siswa Kelas XI Teknik Gambar Bangunan SMK N 1 Padang Tahun 2016/2017. Cived, 5(1), 2175-2182.

Iga, Fathia, A., Agus, W., \& Susanna. (2017). Pengaruh Model Pembelajaran Kooperatif Tipe Snowball Throwing Dengan Percobaan Sederhana Terhadap Hasil Belajar Fisika. Jurnal Ilmiah Mahasiswa (JIM) Pendidikan Fisika, 2(1), 87-91.

Melinda, C., \& Sylvia, I. (2012). Upaya Meningkatkan Kemampuan Berpikir Kritis Siswa Dalam Mata Pelajaran Sejarah Dengan Pembelajaran Trhowing. Diakronika, 12(2), 163-182. https://doi.org/10.31227/osf.io/76cym

Purwanto, P. (2009). Psikologi Pendidikan. Bandung: Rosdakarya.

Raguwan, R., Gonggo, S., \& Sabang, S. (2014). Pengaruh Model Pembelajaran Kooperatif Tipe Snowball Throwing Terhadap Hasil Belajar Siswa Pada Materi Bentuk Molekul Kelas XI IPA SMA Negeri 1 Pasangkayu. Jurnal Akademika Kimia, 3(1), 1-7.

Rasyid, M., \& Side, S. (2011). Pengaruh Penerapan Pembelajaran Snowball Throwing terhadap Hasil Belajar Siswa Kelas X SMAN I Bajeng Kab. Gowa (Studi pada Materi Pokok Senyawa Hidrokarbon). Jurnal Chemica, 12(2), 69-76.

Sanjaya, S. (2009). Strategi Pembelajaran Berorientasi Standar Proses Pendidikan. Jakarta: Kencana.

Jurnal Sikola: Jurnal Kajian Pendidikan dan Pembelajaran Vol. 1, No. 3, Th. 2020 
Sohimin, A. (2014). Model Pembelajaran Inovatif Dalam Kurikulum 2013. Yogyakarta: Ar-Ruz Media.

Sukir, S. (2009). Metode Pembelajaran Inovatif. www.model.pembelajaran.html.

Susanto, H., \& Asto, I G. (2014). Pengaruh Pembelajaran Kooperatif Dengan Metode Snowball Throwing Terhadap Peningkatan Hasil Belajar Siswa Pada Mata Diklat Menerapkan Konsep Elektronika Digital dan Rangkaian Elektronik Komputer Kelas X Tei Di Smk Negeri 3 Jombang, Jurnal Pendidikan Teknik Elektro, 3(3), 328-336.

Sylvia, I., Anwar, S., Khairani, K. (2019). Pengembangan Instrumen Penilaian Autentik Berbasis Pendekatan Authentic Inquiry Learning pada Mata Pelajaran Sosiologi di Sekolah Menengah Atas. 6(2), 103-120. https://doi.org/http://socius.ppj.unp.ac.id/index.php/socius/article/view/ 162

Triastuti, H., Mujasam, Sri, Wahyu, W., \& Irfan, Y. (2017). Penerapan model pembelajaran kooperatif tipe Snowball throwing terhadap hasil belajar Peserta didik. Curricula: Journal of Teaching and Learning, 2(1), 47-58.

Yuli, A., \& Tri, Astuti, A. (2015). Efektifitas Model Pembelajaran Snowball Throwing Melalui Pemanfaatan Prized Chart Terhadap Hasil Belajar Matematika Siswa Kelas VII SMP N 11 Yogyakarta. Jurnal Pendidikan Matematika UNION, 2(3), 221-226.

Zaini, H. (2008). Strategi Pembelajaran Aktif. Yogyakarta: P.I. Madani. 